\title{
Long-term warming manipulations reveal complex decomposition responses across different tundra vegetation types ${ }^{1}$
}

\author{
K. Björnsdóttir, I.C. Barrio, and I.S. Jónsdóttir
}

\begin{abstract}
In a rapidly warming tundra, ecosystems will undergo major environmental changes that are predicted to significantly alter belowground processes such as decomposition of plant litter. Making use of International Tundra Experiment sites (ITEX), which were established approximately two decades ago, we examined the long-term impacts of warming on decomposition. We used the Tea Bag Index (TBI) methodology to measure the annual mass loss (\%) of two tea types as a proxy for potential decomposition rates, across five tundra vegetation types. Direct effects of warming were assessed by comparing mass loss within and outside warming manipulations. Indirect effects of warming, such as those caused by warming-induced changes in plant community composition, were assessed through the relationship between mass loss of tea and local biotic and abiotic conditions. We found positive effects of warming on decomposition, although the responses varied between vegetation and tea types. Interestingly, we found support for the indirect influence of long-term warming on decomposition through warming-induced changes in the composition of plant communities. Our findings demonstrate the complexity in decomposition responses to warming across different vegetation types and highlight the importance of long-term legacies of warming in decomposition responses across the Arctic.
\end{abstract}

Key words: ITEX, Tea Bag Index, decomposition, climate warming, plant-soil interaction.

Résumé : Dans une toundra qui se réchauffe rapidement, les écosystèmes subiront des changements environnementaux majeurs qui, selon les prévisions, modifieront considérablement les processus souterrains, tels que la décomposition de la litière végétale. En utilisant les sites de l'« International Tundra Experiment »(ITEX), établis il y a environ deux décennies, les auteurs ont examiné les impacts à long terme du réchauffement sur la décomposition. Ils ont utilisé la méthodologie de l'indice du sachet de thé (IST) pour mesurer la perte de masse annuelle (\%) de deux types de thé, en tant qu'indicateur des taux de décomposition potentiels, dans cinq types de végétation de la toundra. Les effets directs du réchauffement ont été évalués en comparant la perte de masse dans et hors des manipulations de réchauffement. Les effets indirects du réchauffement, tels que

\footnotetext{
Received 31 October 2020. Accepted 29 March 2021.
}

K. Björnsdóttir* and I.S. Jónsdóttir. ${ }^{\dagger}$ Institute of Life and Environmental Sciences, University of Iceland, Sturlugata 7, 102 Reykjavík, Iceland; University Centre in Svalbard (UNIS), P.O. Box 156, N-9171 Longyearbyen, Norway.

I.C. Barrio. Faculty of Environmental and Forest Sciences, Agricultural University of Iceland, Árleyni 22, Keldnaholt, 112 Reykjavík, Iceland.

Corresponding author: K. Björnsdóttir (e-mail: katrin.bjornsdottir@bioenv.gu.se).

${ }^{1}$ This paper is part of a Special Issue entitled: Impacts of climate change on tundra ecosystems: Three decades of results from the International Tundra Experiment (ITEX).

*Present address: Department of Biological and Environmental Sciences, University of Gothenburg, P.O. Box 461, 40530 Gothenburg, Sweden.

${ }^{\dagger}$ I.S. Jónsdóttir served as Guest Editor and Associate Editor at the time of manuscript review and acceptance; peer review and editorial decisions regarding this manuscript were handled by Philip Wookey and Greg Henry.

Copyright remains with the author(s) or their institution(s). This work is licensed under a Creative Attribution 4.0 International License (CC BY 4.0) http://creativecommons.org/licenses/by/4.0/deed.en_GB, which permits unrestricted use, distribution, and reproduction in any medium, provided the original author(s) and source are credited. 
ceux causés par les changements induits par le réchauffement dans la composition de la communauté végétale, ont été évalués à travers la relation entre la perte de masse de thé et les conditions biotiques et abiotiques locales. Ils ont trouvé des effets positifs du réchauffement sur la décomposition, bien que les réponses varient entre les types de végétation et de thé. Il est intéressant de noter qu'ils ont constaté un soutien pour l'influence indirecte du réchauffement à long terme sur la décomposition par le biais de changements induits par le réchauffement dans la composition des communautés végétales. Ces résultats démontrent la complexité des réponses au réchauffement en matière de décomposition à travers différents types de végétation et soulignent l'importance des legs à long terme du réchauffement dans les réponses de la décomposition à travers l'Arctique. [Traduit par la Rédaction]

Mots-clés : ITEX, indice du sachet de thé, décomposition, réchauffement climatique, interaction plante-sol.

\section{Introduction}

Decomposition of plant litter is an essential component of nutrient and carbon cycling in terrestrial ecosystems, as it enables the mineralization of nutrients and contributes to soil fertility through the formation of humic substances and long-term carbon storage (Berg and Laskowski 2005; Berg and McClaugherty 2014). In tundra ecosystems, microbial activity and decomposition rates are constrained by cold temperatures and low litter quality, but as global temperature continues to rise, this could change (Aerts 2006). While surface temperature is rising globally, warming is even more pronounced in these cold climate regions (Post et al. 2019). Predicted environmental changes in the Arctic due to warming can have substantial consequences for the global carbon cycle, since the Arctic stores a large proportion of the global carbon pool (Schuur et al. 2009; Tarnocai et al. 2009) and therefore has the potential to become a significant carbon source to the atmosphere (Hicks Pries et al. 2011).

The importance of temperature and precipitation as drivers of decomposition is clear (Aerts 2006), but other climate-driven ecosystem changes can also influence decomposition rates. For instance, the structure and composition of many tundra plant communities have become significantly altered in response to warming (Elmendorf et al. 2012b; Bjorkman et al. 2018). The most pronounced vegetation changes in the Arctic are the increased greening trends through the expansion of shrubs (Myers-Smith et al. 2011; Elmendorf et al. 2012a; Berner et al. 2020; Bjorkman et al. 2020) and declines in bryophytes and lichens (Elmendorf et al. 2012a). These changes in plant community composition have the potential to alter the ecosystem carbon balance and nutrient dynamics by shifting the litter composition (Cornelissen et al. 2007), altering soil microclimate (Kemppinen et al. 2019), or influencing soil mycorrhizosphere composition through priming (Parker et al. 2015). Structural changes, such as changes in moss layer depth, could also alter ecosystem dynamics, since mosses regulate soil thermal and hydrological regimes (Gornall et al. 2007, 2009) and thus greatly influence microbial activity in soils. However, plant community responses to warming are not consistent across Arctic regions and tend to be more pronounced in warmer and moister habitats, while colder and drier habitats seem to be more resilient (Elmendorf et al. 2012a). Accurately quantifying the responses of decomposition processes to vegetation changes across different Arctic regions is therefore of particular interest (Cornwell et al. 2008; Bradford et al. 2016; Althuizen et al. 2018).

Despite increased scientific attention, considerable uncertainty remains about the direction and magnitude of warming-induced changes on decomposition processes across the Arctic (Sierra et al. 2015; Sarneel et. al. 2020; Thomas et al. 2018). Coordinated research efforts using standardized methodologies that are comparable across sites will undoubtedly 
help to improve our understanding of the drivers of litter decomposition across this vast and remote region. The Tea Bag Index (TBI) method (Keuskamp et al. 2013) has in recent years gained substantial popularity as a simple, cost-effective, and highly replicable method. The TBI method, which uses two types of commercially available tea - green tea and rooibos tea - as common decomposition substrates representing different litter qualities, allows for comparisons of potential decomposition rates between different ecosystems and soil types (Djukic et al. 2018; Thomas et al. 2018). The two tea types are also good proxies for decomposition of different litter qualities in the tundra, as their decomposability has been found to be representative of leaf litters for a range of Arctic species (Thomas et al. 2018).

Here, we used the TBI method to investigate the effects of climate warming on potential decomposition rates across tundra sites. We studied the mass loss (\%) of standardized litter (tea) in five tundra vegetation types in Iceland and Svalbard, Norway. Making use of experimental sites from the International Tundra Experiment (ITEX) that have been running for approximately two decades, we examined the effects of warming manipulations on potential decomposition rate as well as the indirect, presumably longer term effects of warming, such as those caused by warming-induced changes in plant community composition. We compared mass loss of tea in experimentally warmed plots (open-top chambers; OTCs) with ambient control plots over 12 months, for 2 consecutive years. We aimed to determine (1) how warming manipulations affect potential decomposition rates in five contrasting tundra vegetation types and (2) how potential decomposition is related to local environmental characteristics in soil temperature and soil moisture or long-term warminginduced changes in plant community composition and structure (plant and litter abundance and moss depth).

We hypothesized that potential decomposition would increase within the experimentally warmed plots, compared with control plots (H1), since temperature is known to be a major driver of decomposition (Aerts 2006). Similarly, we expected that these decomposition responses to warming would depend on how biotic and abiotic local environmental conditions have responded to the long-term warming manipulations (H2). Specifically, we predicted that a decrease in soil moisture in the warming treatments would be negatively related to potential decomposition, as soil moisture is often a limiting factor of decomposition where water availability is low (Hicks Pries et al. 2013). In addition, we expected changes in plant community composition and structure in response to long-term warming to influence the potential decomposition rate.

\section{Methods}

Study sites

The study was conducted in subarctic Iceland and high Arctic Svalbard, Norway, two regions with contrasting bioclimatic conditions (Fig. 1). In Iceland, experiments were established in two different vegetation types: moss heath (MH) in Pingvellir in 1995 and a Betula nana heathland (BH) in Auðkúluheiði in 1996.

Auðkúluheiði is located in the northwestern highlands of Iceland $\left(65^{\circ} 26^{\prime} \mathrm{N}, 20^{\circ} 25^{\prime} \mathrm{W}\right)$ at $480 \mathrm{~m}$ elevation, above the potential tree line. It is therefore characterized as subarcticalpine, resembling low Arctic tundra conditions. The climate is typically oceanic-subarctic, with a mean annual temperature of $0.7 \pm 0.3{ }^{\circ} \mathrm{C}$ and mean annual precipitation of $357 \pm 14$ mm (1996-2017; Kolka weather station, Icelandic Meteorological Office 2018). The bedrock is basalt covered with loose glacial deposits, and the soils are classified as well-drained Brown Andosols (Jónsdóttir et al. 2005; Arnalds 2015). BH is dominated by the dwarf shrub Betula nana, together with Empetrum nigrum, Salix arctica, and Carex bigelowii; Racomitrium lanuginosum is the dominant moss species (Jónsdóttir et al. 2005). 
Fig. 1. Location of the study sites. Endalen in high Arctic Svalbard, Norway (green; $78^{\circ} 11^{\prime} \mathrm{N}, 15^{\circ} 45^{\prime} \mathrm{E}$ ); a subarcticalpine site in Auðkúluheiði, Iceland (orange; $65^{\circ} 26^{\prime} \mathrm{N}, 20^{\circ} 25^{\prime} \mathrm{W}$ ); and a subarctic site in Pingvellir, Iceland (red; $64^{\circ} 28^{\prime} \mathrm{N}, 21^{\circ} 08^{\prime} \mathrm{W}$ ). Warming experiments were established in three vegetation types in Endalen (Dryas heath $(\mathrm{DH})$, Cassiope heath $(\mathrm{CH})$, and snowbed $(\mathrm{SB})$ community); a Betula heath $(\mathrm{BH})$ in Auðkúluheiði; and a moss heath $(\mathrm{MH})$ in Pingvellir. The map was created in the R programming language using the packages ggplot2 (Wickham 2009) and rworldmap (South 2016).

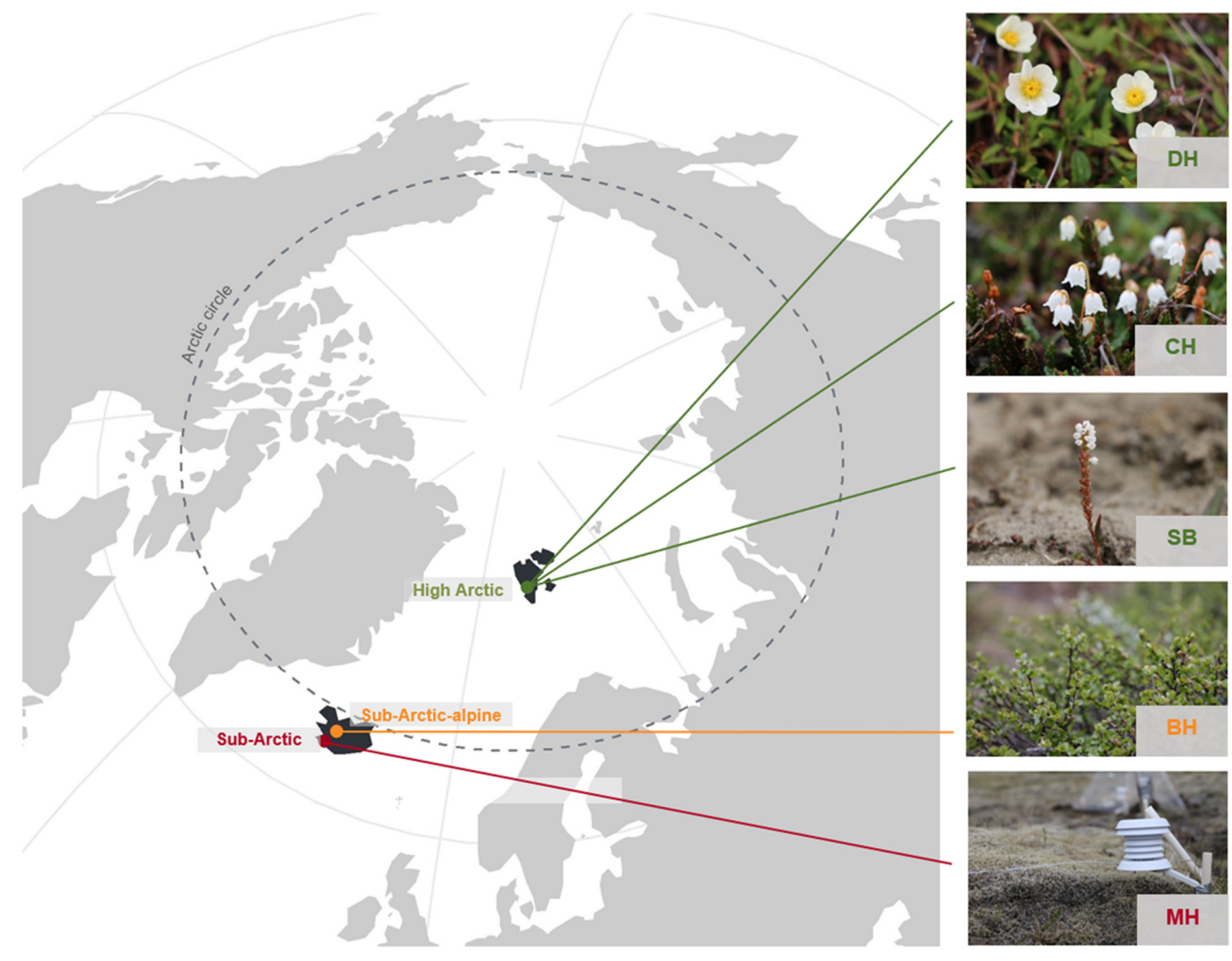

The moss heath is located on an 8000-year-old basaltic lava field within Pingvellir National Park in southwestern Iceland $\left(64^{\circ} 28^{\prime} \mathrm{N}, 21^{\circ} 08^{\prime} \mathrm{W}\right)$ at $120 \mathrm{~m}$ elevation. It is characterized as subarctic slightly below the potential tree line. The climate is oceanic-subarctic, with a mean annual temperature of $4.1 \pm 0.3{ }^{\circ} \mathrm{C}$ and mean annual precipitation of $1242 \pm 37$ mm (1996-2017; Pingvellir weather station, Icelandic Meteorological Office 2018). Soil types are classified as Brown Andosols with high organic matter content and relatively nutrient poor (Jónsdóttir et al. 2005). The plant community is dominated by the moss Racomitrium lanuginosum, which forms a thick continuous layer. The vascular plant cover is less than 10\%, and the most common species are Carex bigelowii, Festuca richardsonii, and Galium boreale.

In Svalbard, experiments were established in 2002 in three different vegetation types, all located at $80 \mathrm{~m}$ elevation on a south-southeast-facing hillside of the Endalen valley $\left(78^{\circ} 11^{\prime} \mathrm{N}, 15^{\circ} 45^{\prime} \mathrm{E}\right), \sim 4 \mathrm{~km}$ east of Longyearbyen. Mean annual temperature for 1981-2010 was $-5.2^{\circ} \mathrm{C}$ and mean annual precipitation was $191 \mathrm{~mm}$ (Førland et al. 2011). The soils are Cryosols with a thin organic layer on top of inorganic sediments (Jones et al. 2010). The three vegetation types are shaped by differences in snow depth during winter and at 
snowmelt in spring (and hence the length of the growing season): Dryas heath (DH) has a thin snow cover $(\sim 10 \mathrm{~cm})$ and early snowmelt; the mesic Cassiope heath $(\mathrm{CH})$ has intermediate snow depth and melts out at a mean of $12 \pm 3$ days later than DH; and the moist snowbed (SB) community has deep snow $(>100 \mathrm{~cm})$ and melts out $24 \pm 3$ days later than DH. In DH, the evergreen shrub Dryas octopetala is the dominant vascular plant species and Sanionia uncinata is the dominant moss species. In addition, Salix polaris, Saxifraga oppositifolia, Bistorta vivipara, and Carex rupestris commonly occur. In $\mathrm{CH}$, the dominant vascular plant species is Cassiope tetragona, and the most abundant moss species are Tomentypnum nitens and Sanionia uncinata. Salix polaris and Bistorta vivipara are also abundant. In SB, the moss cover is substantial and dominated by Tomentypnum nitens, and Sanionia uncinata is also common. The vascular plant cover is relatively low and dominated by Bistorta vivipara, Salix polaris, and the grasses Poa arctica and Festuca richardsonii.

\section{Experimental design}

In 2016, when the decomposition trials started, warming experiments had been running at the sites for 14 years (Svalbard) and 21 years (Iceland). Following the ITEX protocol, climate warming was simulated using OTCs, which raise the mean daily air temperature by $1-2{ }^{\circ} \mathrm{C}$, on average (Molau and Mølgaard 1996). A total of 70 permanent plots $(75 \mathrm{~cm} \times$ $75 \mathrm{~cm}$ ) were used in this study, 35 with warming treatments (OTC) and 35 ambient control plots (CTL). The number of plots differed between vegetation types (Supplementary Table $\left.S 1^{1}\right)$. In Iceland, 20 plots were established in pairs in each vegetation type, and the treatments (OTC or CTL) were assigned randomly to one of the plots in each pair (10 plots per treatment). In Svalbard, 10 plots were established in each vegetation type, and treatments (OTC or CTL) were assigned randomly to the plots (five plots per treatment).

\section{Data collection and processing}

Following the protocols of the TBI method, potential litter decomposition was quantified using two types of commercially available tea, green tea (EAN 872270005552 5) and rooibos tea (EAN 872270018843 8) (Keuskamp et al. 2013). Because of large climatic annual variation in the Arctic, we assessed mass loss of tea over 2 consecutive years. Tea bags were weighed before installation in the field in the beginning of the growing season (June) in 2016 and 2017 (for exact dates see Supplementary Table $S 1^{1}$ ). Four pairs of rooibos and green tea bags were buried into the soil $(8 \pm 2 \mathrm{~cm}$ deep) within the experimental plots, avoiding disturbance to the long-term monitoring plots. Tea bags were collected after an incubation period of either 3 months (two pairs of tea bags) or 12 months (two pairs of tea bags). Only the data from the 12-month incubation are presented here, but stabilization factors $(S)$ and decomposition rates $(k)$ calculated from the 3-month incubation data are presented as Supplementary material (Supplementary Fig. S3 ${ }^{1}$ ) for comparison with other TBI studies (also see the Extended methods in the Supplementary material ${ }^{1}$ ). Upon retrieval, tea bags were dried at $70{ }^{\circ} \mathrm{C}$ for $48 \mathrm{~h}$, and any attached soil or roots were removed before weighing the remaining tea mass. The relative mass loss was calculated by subtracting the final tea mass from the initial tea mass before incubation. A total of 560 tea bags were used for this study.

\section{Environmental and plant community variables}

The effect of the warming manipulations on soil temperature was monitored using soil temperature loggers (DS1921G Thermochron iButtons, Milton Keynes, UK, or Gemini Tiny tags, West Sussex, UK) in August 2016 and 2017. Owing to logger failure, no soil temperature

\footnotetext{
${ }^{1}$ Supplementary material is available with the article at https://doi.org/10.1139/as-2020-0046.
} 
data were available for $\mathrm{MH}$, and data were only available for 2016 in BH. Soil moisture was measured in all plots with a handheld moisture meter (HH2 Moisture Meter and ML2x ThetaProbe, Delta-T Devices Ltd., England) in early summer 2016 and 2017, at the time of tea bag installation. In addition, moss depth was measured $(\mathrm{cm})$ above the burial place of each tea bag in 2016, in all vegetation types except for MH. There, data on moss depth was obtained from measurements conducted in 2014 from the middle of each plot.

We explored available data from the sites on change in plant community composition and litter abundance in response to OTC treatments (for more details see the Extended methods in the Supplementary material $\left.{ }^{1}\right)$. The abundance of litter and three plant functional groups (deciduous shrubs, evergreen shrubs, and bryophytes) responded to the long-term experimental warming manipulations at one or more sites, so the abundances of these groups in the final year of plant community assessment were used in our analysis.

\section{Data analysis}

To address question 1 - how decomposition responds to long-term experimental warming - linear mixed effect models were built for the two response variables, mass loss (\%) of green and rooibos tea. The fixed effects in the initial model included the three-way interaction between treatments (OTC and CTL), vegetation type (BH, MH, DH, $\mathrm{CH}$, and SB), and year (2016 vs. 2017). To account for the nested study design (i.e., several teabags within each plot), we included plot identity as a random factor. We reduced the models by dropping nonsignificant interactions from the models by comparing the models with and without the interactions with analysis of variance (ANOVA). Where relevant, the model coefficient estimates, degrees of freedom (df), and $p$ values are reported in the text. Model estimates for the linear mixed-effect models are reported in Supplementary Table S2 ${ }^{1}$.

The effects of long-term experimental warming manipulations on local environmental variables (soil temperature and soil moisture), as well as plant functional abundance (deciduous shrubs, evergreen shrubs, bryophytes, and litter) and moss depth after longterm warming, were compared using $t$ tests. Where relevant, $t$ values, df, and $p$ values are reported in the text.

To address question 2, we explored the relationship between the mass loss of green tea and local environmental conditions (soil temperature, soil moisture, moss depth, and abundance of plant functional types) using multiple regression analysis over both years for each vegetation type (five models in total). The response variables were the mean mass loss of green tea over both years in each plot. Pearson correlations were used to evaluate collinearity between environmental predictor variables, and highly correlated variables $(r>0.7)$ were excluded from the models. In $\mathrm{BH}$, the abundance of deciduous shrubs was positively correlated with abundance of litter $(r=0.81)$ and negatively correlated with soil temperature $(r=-0.71)$ and moss depth $(r=-0.75)$; these three variables were therefore dropped before model selection. Model selection followed a backward procedure using Akaike's information criterion (AIC) where predictor variables were only dropped if they reduced the AIC score by more than two (Burnham and Anderson 2002).

All statistical analyses were performed in the $\mathrm{R}$ environment version 4.0.0 ( $\mathrm{R}$ Core Team 2019), using the packages lme4 (Bates et al. 2015), lmerTest (Kuznetsova et al. 2017), MASS (Ripley et al. 2020), tidyverse (Wickham et al. 2019), ggplot2 (Wickham 2009), and lubridate (Grolemund and Wickham 2011). 
Fig. 2. Decomposition responses to long-term experimental warming in five different vegetation types in Iceland (BH, Betula heath; MH, moss heath) and Svalbard, Norway (DH, Dryas heath; CH, Cassiope heath; SB, snowbed community). Mass loss (\%) of green tea (green) and rooibos tea (red) is shown in ambient control plots (circles) and warming treatments (triangles). The data are presented as means for 12-month incubation periods with standard errors (bold lines) and 95\% confidence intervals (thin lines) for the years 2016 and 2017. Asterisks indicate significant differences in mass loss of tea between treatments $\left({ }^{* *}, p<0.001\right.$; $\left.{ }^{* * *}, p<0.0001\right)$ within each vegetation type.

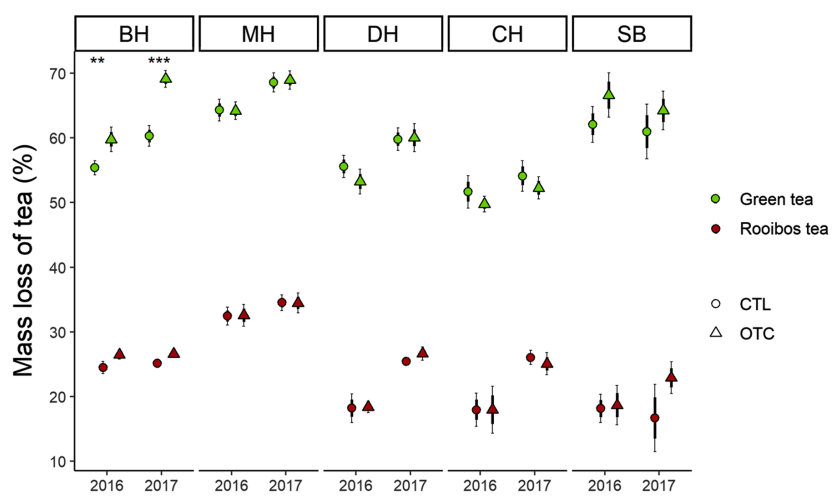

\section{Results}

Decomposition responses to long-term warming manipulations

In general, decomposition of green and rooibos tea was faster in the Icelandic vegetation types than in Svalbard (Fig. 2). For the mass loss of green tea, a significant interaction was detected between treatment and vegetation type $\left.\chi^{2}=25.1 \mathrm{df}=4, p<0.001\right)$ (Fig. 2) and between vegetation type and year $\left(\chi^{2}=33.7, \mathrm{df}=4, p<0.001\right)$ (Supplementary Fig. $S 1^{1}$ ), indicating that the effect of warming on decomposition of green tea differed between vegetation types and that decomposition of green tea differed between 2016 and 2017 in some of the vegetation types. In $\mathrm{BH}$, the warming treatments resulted in a significantly larger mass loss of green tea in both years, with 8\% and 14\% increases in 2016 and 2017, respectively (Fig. 2). In contrast, warming treatments in $\mathrm{DH}$ and $\mathrm{CH}$ resulted in a slightly decreased mass loss of green tea, although no significant difference was detected (Fig. 2). For mass loss of rooibos tea, no significant interaction was found between treatment and vegetation type $\left(\chi^{2}=5.8, \mathrm{df}=4, p=0.25\right)$, although a significant interaction between vegetation type and year was detected $\left(\chi^{2}=41.2, \mathrm{df}=4, p<0.001\right.$ ) (Supplementary Fig. S1 ${ }^{1}$ ).

\section{Local environmental characteristics in the experimental treatments}

Overall, August soil temperature was higher in 2017 than in 2016. The impact of the warming treatments almost consistently resulted in increased soil temperature, except in $\mathrm{BH}$, where the treatment significantly decreased soil temperature by $1.58{ }^{\circ} \mathrm{C}(t=8.63$, $\mathrm{df}=58.5, p<0.001$; Supplementary Fig. S2 ${ }^{1}$ ). Although no statistically significant effects of the OTCs on soil temperature were detected in any of the three high Arctic habitats (Supplementary Fig. S2 ${ }^{1}$ ), the OTC plots in DH were, on average, $0.96{ }^{\circ} \mathrm{C}$ warmer than the control plots, and in SB (in 2017) they were $0.89^{\circ} \mathrm{C}$ warmer than the control plots.

Soil moisture differed between vegetation types and years. In $\mathrm{BH}$, soil moisture was higher in 2017 than in 2016, while the opposite occurred in the three high Arctic vegetation types (DH, CH, SB). The warming treatments consistently resulted in drier conditions in almost all vegetation types for both years, but these differences were significant only in DH $(t=2.94, \mathrm{df}=36, p=0.006), \mathrm{CH}(t=3.19, \mathrm{df}=28, p=0.004)$, and $\mathrm{MH}(t=2.78, \mathrm{df}=68.1$, $p=0.007$ ) in 2016 (Supplementary Fig. S2 ${ }^{1}$ ). 
Table 1. Multiple regression models for effects of local environmental variables on mass loss (\%) of green tea in five different vegetation types in Iceland (BH, Betula heath; $\mathrm{MH}$, moss heath) and Svalbard (DH, Dryas heath; CH, Cassiope heath; SB, snowbed community).

\begin{tabular}{lllll}
\hline Habitat & Model & Adjusted $R^{2}$ & $p$ value & $\begin{array}{l}\text { \% variance } \\
\text { explained }\end{array}$ \\
\hline Betula heath & Soil moisture + SDECI + SEVER + MOSS & 0.56 & $<\mathbf{0 . 0 1}$ & 65.0 \\
Moss heath & LITTER & 0.003 & 0.32 & 5.58 \\
Dryas heath & SDECI + MOSS & 0.31 & 0.11 & 46.7 \\
Cassiope heath & Soil moisture & 0.03 & 0.28 & 14.4 \\
Snowbed & Soil temperature + SDECI + SEVER + MOSS & 0.67 & $\mathbf{0 . 0 4}$ & 81.9 \\
\hline
\end{tabular}

Note: Environmental variables included in the models are as follows: soil moisture; soil temperature; abundance of deciduous shrubs (SDECI); evergreen shrubs (SEVER); bryophytes (MOSS); and litter (LITTER). Models that are statistically significant are shown in bold $(p<0.05)$.

Overall, the moss depth was greatest in $\mathrm{MH}$, where the warming treatments significantly increased moss depth by $1.84 \mathrm{~cm}(t=-3.91, \mathrm{df}=55.2, p<0.001)$. In the other vegetation types, however, the warming treatments either resulted in a decrease in moss depth or had no impact. In $\mathrm{BH}$, the OTCs significantly decreased depth of the moss layer by $2.56 \mathrm{~cm}$ $(t=4.27, \mathrm{df}=73, p<0.001)$, and in SB by $0.96 \mathrm{~cm}(t=2.41, \mathrm{df}=34.0, p=0.021)$, while no impact on moss depth was detected in $\mathrm{DH}$ and $\mathrm{CH}$.

\section{Relationship between decomposition and local environmental variables}

Local environmental variables, irrespective of the warming treatments, had no effect on mass loss of green tea in $\mathrm{MH}, \mathrm{DH}$, and $\mathrm{CH}$. However, these local environmental factors affected mass loss in $\mathrm{BH}(\mathrm{F}=6.9, \mathrm{df}=15, p<0.01)$ and in $\mathrm{SB}(\mathrm{F}=5.7, \mathrm{df}=5, p=0.04)$ (Table 1; Fig. 3). In $\mathrm{BH}$, the model that best described the effect of environmental conditions on mass loss of green tea explained $65 \%$ of the variation and included factors representing the abundance of deciduous shrubs, evergreen shrubs, bryophytes, and soil moisture (Table 1). The only significant predictor was the abundance of deciduous shrubs, which had a significant positive effect on mass loss of green tea (estimate \pm standard error (SE): $0.13 \pm 0.03, p<0.001)$. In SB, the best model selected explained $82 \%$ of the variation and included factors representing soil temperature, abundance of deciduous shrubs, evergreen shrubs, and bryophytes (Table 1).

\section{Discussion}

Our results demonstrate the complexity in decomposition responses to warming across different vegetation types in the Arctic. We found that the experimental warming manipulations affected potential decomposition rates, but these effects varied between vegetation types and types of tea. Interestingly, we found support for the influence of long-term warming on decomposition through warming-induced changes in the composition and structure of plant communities in the Betula heath in Iceland. The moss heath in Iceland and the three vegetation types in Svalbard, however, seemed to be more resilient to long-term warming manipulations.

Partly supporting the hypothesis that decomposition rate increases with warmer temperature, as other studies have previously reported (e.g., Aerts 2006; Davidson and Janssens 2006), we observed a consistent increase in mass loss of the more labile tea (green tea) within the warming treatments in BH over 2 consecutive years. Although the labile green tea responded to the warming treatments within the 12-month incubation period, no responses to warming were detected for the more recalcitrant rooibos tea. This aligns with findings from other studies that have used the TBI approach (Sarneel et al. 2020), but the mechanisms explaining this response remain poorly understood. In addition, no 
Fig. 3. Relationship between mass loss (\%) of green tea with environmental variables - soil temperature (A), soil moisture (B), abundance of deciduous shrubs $(C)$, abundance of evergreen shrubs (D), litter abundance (E), and bryophyte abundance $(\mathrm{F})$ - in the five studied vegetation types: Betula heath (BH; blue, circle), moss heath (MH; white, reversed triangle), Dryas heath (DH; red, square), Cassiope heath (CH; green, diamond), and snowbed community (SB; yellow, triangle). The presence of a statistical relationship is indicated with a solid line $(p<0.05)$, and the absence of one is indicated with a broken line.
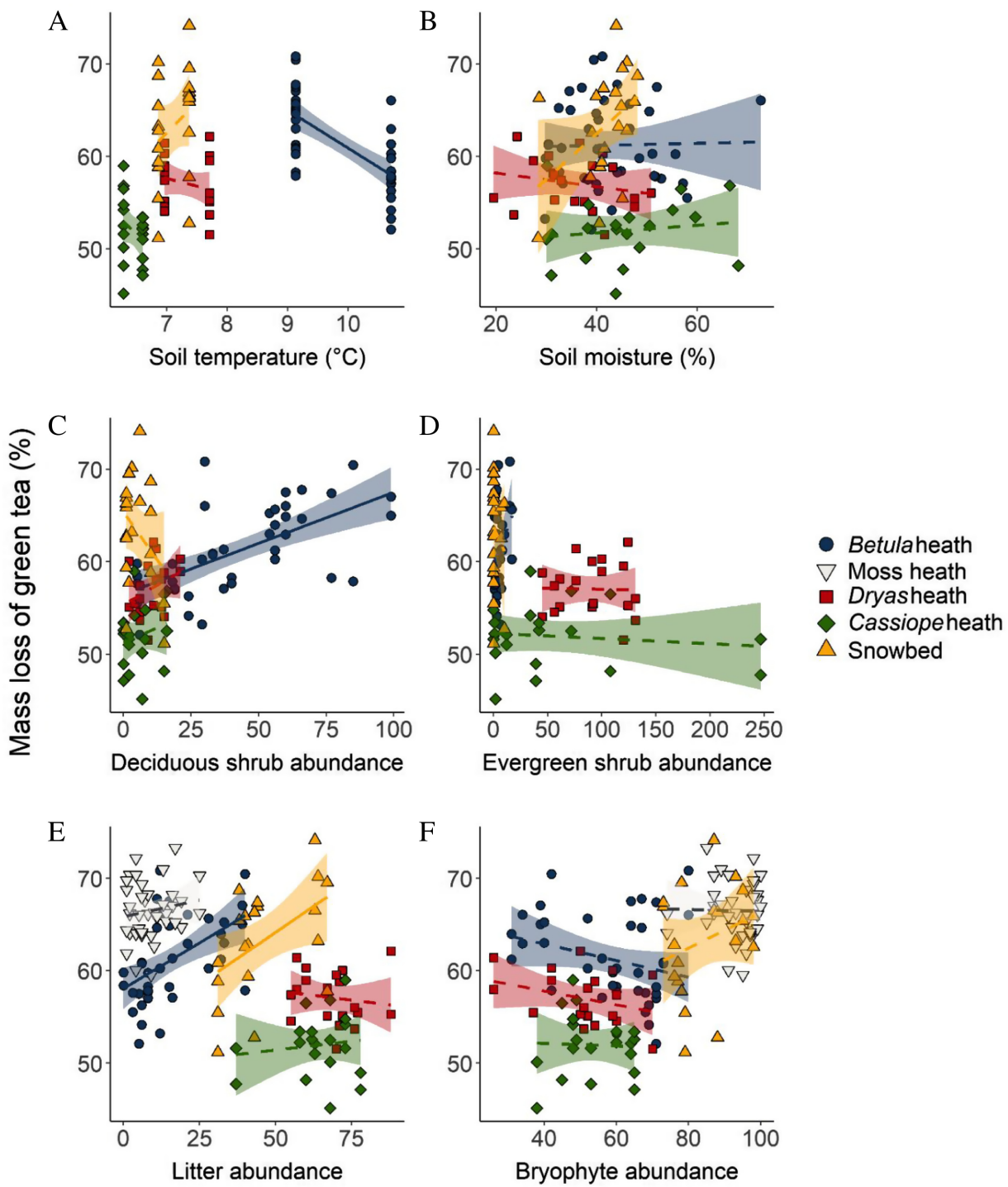

responses in mass loss of green nor rooibos tea to the warming treatments were found in the other four vegetation types.

During the 20-year experimental warming manipulation, significant community changes were detected in BH in Iceland (Jónsdóttir et al. 2005), with increased abundance of deciduous shrubs over time, especially within the warming treatments. Our models suggest a positive effect of the abundance of deciduous shrubs on mass loss of green tea, although these effects could also be explained by a positive effect of litter increase and 
negative effects of lower soil temperatures in the OTCs, as these variables were strongly correlated. The models that best described the effects of environmental conditions on mass loss of green tea in $\mathrm{BH}$ explained a moderate amount of variation (65\%), suggesting that the factors influencing the mass loss of green tea are more complex than we can account for in our models.

The shift in plant growth-form composition, where forbs and bryophytes are replaced by deciduous shrubs, has been reported, or hypothesized, to contribute to increased carbon storage through various processes (Cahoon et al. 2012; Myers-Smith and Hik 2013). For instance, increased production of shrub litter, which is more recalcitrant than herbaceous litter (Cornelissen et al. 2007), and changes in soil microclimate by increased shading and insulation (decreasing summer soil temperature) (Kemppinen et al. 2019) may contribute to slower decomposition and increased soil carbon storage. However, this does not seem to be the case in the Betula heath in our study, where mass loss of the more labile tea was accelerated within the warming treatments in spite of increased shading by shrubs and colder August soil temperature. This suggests that changes in vegetation composition and structure, with the associated changes in litter composition and rhizosphere and soil microbial community structure, could act as a stronger driver of decomposition of labile material in the Betula heath than the physical microenvironmental conditions in soil moisture and soil temperature.

The potential role of deciduous shrubs as a driver of decomposition has been demonstrated in a study across 16 ITEX experimental sites showing high bacterial abundance in litter at sites dominated by deciduous shrubs (Jeanbille et al. 2021) and in a study showing a relatively fast decomposition rate for Betula litter (McLaren et al. 2017). In addition, there is evidence indicating that increased soil carbon loss is associated with enhanced shrub and tree growth in tundra environments (Hartley et al. 2012; Parker et al. 2015; Christiansen et al. 2018; Street et al. 2020). Street et al. (2020) concluded that the expansion of shrubs might increase decomposition of older soil organic carbon caused through a rhizosphere priming effect, a process whereby increased carbon transfer caused by root activity stimulates decomposition of older soil organic matter (Street et al. 2020). Likewise, Christiansen et al. (2018) found that decomposition of recalcitrant carbon in Betula neoalaskana litter was accelerated in tall birch shrub $(\sim 0.8 \mathrm{~m})$ environments. They concluded that the biotic feedback associated with tall birch shrub environments was a stronger driver of nutrient cycling than the soil microclimate alone. It is possible that similar processes also counteracted the negative effects of decreased soil temperature, caused by shading and insulation, in the Betula heath in our study.

In the Betula heath in Iceland, the increased abundance in deciduous shrubs is in particular due to the enhanced growth of the deciduous dwarf shrub Betula nana, especially within the warming treatments. Certain phenotypic traits of this species, including developmental plasticity and formation of mycorrhizal networks, which facilitate carbon transfer in the soil, promote the species' success in outcompeting other species (Bret-Harte et al. 2001; Deslippe and Simard 2011). Associated with this increased Betula nana growth, litter accumulation had increased significantly within the OTCs. Although an increase in litter accumulation is expected with increased shrub productivity, the confounding effect of the OTC design on litter accumulation needs to be acknowledged. The plexiglass side panels of the OTCs inevitably provide shelter from wind (De Boeck et al. 2012; Bokhorst et al. 2013) and intercept precipitation, which could create conditions for litter accumulation within the chambers. This could have implications for belowground processes, as larger shrub litter inputs can lead to internal biotic feedback mechanisms that prime microbial decomposition (Christiansen et al. 2018). 
Although many Arctic communities are sensitive to warming-induced environmental changes, such as the ones we observed in the Betula heath in Iceland, other ecosystems do not respond as strongly to decades of climate warming (Hudson and Henry 2010), in particular the sites of interest in this study in the high Arctic (I.S. Jónsdóttir et al., unpublished data). After 12 years of warming, in Endalen, Svalbard, only small community changes were detectable. In $\mathrm{DH}$, the abundance of evergreen shrubs had increased significantly, as reflected in the increase of the dominating evergreen shrub, Dryas octopetala, while long-term warming had no effect on plant community composition in $\mathrm{CH}$ or SB. The same pattern was observed in $\mathrm{MH}$ in Iceland, where we observed negligible community changes after 16 years of warming. The lack of response to warming manipulations with respect to potential decomposition rate as well as changes in plant community composition, as we observed here, illustrates the complexity in responses of tundra ecosystems to climate warming and potential ecosystem-climate feedback processes.

In conclusion, our results indicate that climate warming stimulates the decomposition rate in subarctic-alpine tundra (reflecting low Arctic conditions), while in the high Arctic and a moss-dominated subarctic habitat, belowground processes could be more resilient to decadal climate warming. We found evidence that the biotic mechanisms controlling long-term warming-induced changes in plant community composition serve as the main driver in decomposition processes, overriding the effects of changes in soil microclimatic conditions. In our study, we assumed that the species within our vegetation types would respond to environmental conditions in the same way as the tea litter we incubated, and although the use of standardized tea is useful when comparing the potentials for decomposition across sites, the actual decomposition rates also need to be evaluated based on site-specific litter.

If temperature continues to rise as predicted, plant-soil interactions will become increasingly important in determining associated carbon release into the atmosphere. These processes can have pronounced repercussions for the tundra carbon storage, as they ultimately can result in a positive feedback to climate warming if increased carbon turnover exceeds the rate of carbon uptake from higher plant growth (Cornwell et al. 2008). Our study provides field-based evidence that the responsiveness of plant communities to warming could, in part, determine shifts in decomposition rates in some Arctic tundra environments, and these shift needs to be considered when estimating the climate feedback to the global carbon cycle.

\section{Acknowledgements}

The study was financed by the University of Iceland Research Fund (2016 and 2017) and the University Centre in Svalbard, UNIS (grants to I.S.J.). The Agricultural University of Iceland also provided funding from Blikastaðasjóður during the writing process. The authors are grateful for field and lab assistance from Anne-Nikolai Hejkoop, Carmen Klausbruchner, Matteo Petit Bon, Hanna Böhner, Paula Miguel, Ana Judith Russi-Colmenares, Kristen Peck, and Gunnhildur Gísladóttir. We also thank Anne D. Bjorkman, who kindly provided comments on an earlier draft of the manuscript, as well as two anonymous reviewers for comments that greatly improved the manuscript.

\section{References}

Aerts, R. 2006. The freezer defrosting: global warming and litter decomposition rates in cold biomes. J. Ecol. 94: 713-724. doi: 10.1111/j.1365-2745.2006.01142.x.

Althuizen, I.H.J., Lee, H., Sarneel, J.M., and Vandvik, V. 2018. Long-term climate regime modulates the impact of short-term climate variability on decomposition in alpine grassland soils. Ecosystems, 21: 1580-1592. doi: 10.1007/s10021-018-0241-5.

Arnalds, O. 2015. The soils of Iceland. Springer. doi: 10.1007/978-94-017-9621-7. 
Bates, D., Mächler, M., Bolker, B.M., and Walker, S.C. 2015. Fitting linear mixed-effects models using lme4. J. Stat. Softw. 67: 1-48. doi: 10.18637/jss.v067.i01.

Berg, B., and Laskowski, R. 2005. Introduction. In Litter decomposition: a guide to carbon and nutrient turnover. Edited by B. Berg and R. Laskowski. Academic Press. pp. 1-17. doi: 10.1016/S0065-2504(05)38001-9.

Berg, B., and McClaugherty, C. (Editors). 2014. Plant litter: decomposition, humus formation, carbon sequestration. 3rd ed. Springer Verlag, Berlin, Heidelberg, Germany.

Berner, L.T., Massey, R., Jantz, P., Forbes, B.C., Macias-Fauria, M., Myers-Smith, I., et al. 2020. Summer warming explains widespread but not uniform greening in the Arctic tundra biome. Nat. Commun. 11: 4621. doi: 10.1038/ s41467-020-18479-5. PMID: 32963240.

Bjorkman, A.D., Myers-Smith, I.H., Elmendorf, S.C., Normand, S., Rüger, N., Beck, P.S.A., et al. 2018. Plant functional trait change across a warming tundra biome. Nature, 562: 57-62. doi: 10.1038/s41586-018-0563-7. PMID: 30258229.

Bjorkman, A.D., García Criado, M., Myers-Smith, I.H., Ravolainen, V., Jónsdóttir, I.S., Westergaard, K.B., et al. 2020. Status and trends in Arctic vegetation: evidence from experimental warming and long-term monitoring. Ambio, 49: 678-692. doi: 10.1007/s13280-019-01161-6. PMID: 30929249.

Bokhorst, S., Huiskes, A., Aerts, R., Convey, P., Cooper, E., Dalen, L., et al. 2013. Variable temperature effects of Open Top Chambers at polar and alpine sites explained by irradiance and snow depth. Global Change Biol. 19: 64-74. doi: 10.1111/gcb.12028. PMID: 23504721.

Bradford, M.A., Berg, B., Maynard, D.S., Wieder, W.R., and Wood, S.A. 2016. Understanding the dominant controls on litter decomposition. J. Ecol. 104: 229-238. doi: 10.1111/1365-2745.12507.

Bret-Harte, M.S., Shaver, G.R., Zoerner, J.P., Johnstone, J.F., Wagner, J.L., Chavez, A.S., et al. 2001. Developmental plasticity allows Betula nana to dominate tundra subjected to an altered environment. Ecology, 82: 18-32. doi: 10.1890/0012-9658(2001)082[0018:DPABNT]2.0.CO;2.

Burnham, K.P., and Anderson, D.R. 2002. Model selection and multimodel inference: a practical informationtheoretic approach. 2nd ed. Springer-Verlag, New York, N.Y., USA.

Cahoon, S.M.P., Sullivan, P.F., Shaver, G.R., Welker, J.M., and Post, E. 2012. Interactions among shrub cover and the soil microclimate may determine future Arctic carbon budgets. Ecol. Lett. 15: 1415-1422. doi: 10.1111/j.14610248.2012.01865.x. PMID: 22938383.

Christiansen, C.T., Mack, M.C., DeMarco, J., and Grogan, P. 2018. Decomposition of senesced leaf litter is faster in tall compared to low birch shrub tundra. Ecosystems, 21: 1564-1579. doi: 10.1007/s10021-018-0240-6.

Cornelissen, J.H.C., van Bodegom, P.M., Aerts, R., Callaghan, T.V., van Logtestijn, R.S.P., Alatalo, J., et al. 2007. Global negative vegetation feedback to climate warming responses of leaf litter decomposition rates in cold biomes. Ecol. Lett. 10: 619-627. doi: 10.1111/j.1461-0248.2007.01051.x. PMID: 17542940.

Cornwell, W.K., Cornelissen, J.H.C., Amatangelo, K., Dorrepaal, E., Eviner, V.T., Godoy, O., et al. 2008. Plant species traits are the predominant control on litter decomposition rates within biomes worldwide. Ecol. Lett. 11: 1065-1071. doi: 10.1111/j.1461-0248.2008.01219.x. PMID: 18627410.

Crowther, T.W., Todd-Brown, K.E.O., Rowe, C.W., Wieder, W.R., Carey, J.C., MacHmuller, M.B., et al. 2016. Quantifying global soil carbon losses in response to warming. Nature, 540: 104-108. doi: 10.1038/nature20150. PMID: 27905442.

Davidson, E.A., and Janssens, I.A. 2006. Temperature sensitivity of soil carbon decomposition and feedbacks to climate change. Nature, 440: 165-173. doi: 10.1038/nature04514. PMID: 16525463.

De Boeck, H.J., De Groote, T., and Nijs, I. 2012. Leaf temperatures in glasshouses and open-top chambers. New Phytol. 194: 1155-1164. doi: 10.1111/j.1469-8137.2012.04117.x. PMID: 22448800.

Deslippe, J.R., and Simard, S.W. 2011. Below-ground carbon transfer among Betula nana may increase with warming in Arctic tundra. New Phytol. 192: 689-698. doi: 10.1111/j.1469-8137.2011.03835.x. PMID: 21797881.

Djukic, I., Kepfer-Rojas, S., Schmidt, I.K., Larsen, K.S., Beier, C., Berg, B., et al. 2018. Early stage litter decomposition across biomes. Sci. Total Environ. 628-629: 1369-1394. doi: 10.1016/j.scitotenv.2018.01.012. PMID: 30045558.

Elmendorf, S.C., Henry, G.H.R., Hollister, R.D., Björk, R.G., Bjorkman, A.D., Callaghan, T.V., et al. 2012a. Global assessment of experimental climate warming on tundra vegetation: heterogeneity over space and time. Ecol. Lett. 15: 164-175. doi: 10.1111/j.1461-0248.2011.01716.x.

Elmendorf, S.C., Henry, G.H.R., Hollister, R.D., Björk, R.G., Boulanger-Lapointe, N., Cooper, E.J., et al. $2012 b$. Plot-scale evidence of tundra vegetation change and links to recent summer warming. Nat. Clim. Change, 2 : 453-457. doi: 10.1038/nclimate1465.

Førland, E.J., Benestad, R., Hanssen-Bauer, I., Haugen, J.E., and Skaugen, T.E. 2011. Temperature and precipitation development at Svalbard 1900-2100. Adv. Meteorol. 2011: 1-14. doi: 10.1155/2011/893790.

Gornall, J.L., Jónsdóttir, I., Woodin, S., and van der Wal, R. 2007. Arctic mosses govern below-ground environment and ecosystem processes. Oecologia, 153: 931-941. doi: 10.1007/s00442-007-0785-0. PMID: 17618466.

Gornall, J.L., Woodin, S.J., Jónsdóttir, I.S., and Van der Wal, R. 2009. Herbivore impacts to the moss layer determine tundra ecosystem response to grazing and warming. Oecologia, 161: 747-758. doi: 10.1007/s00442-009-1427-5. PMID: 19701775.

Grolemund, G., and Wickham, H. 2011. Dates and times made easy with lubridate. J. Stat. Softw. 40: 1-25. doi: 10.18637/jss.v040.i03.

Hartley, I.P., Garnett, M.H., Sommerkorn, M., Hopkins, D.W., Fletcher, B.J., Sloan, V.L., et al. 2012. A potential loss of carbon associated with greater plant growth in the European Arctic. Nat. Clim. Change, 2: 875-879. doi: 10.1038/ nclimate1575. 
Hicks Pries, C.E., Schuur, E.A.G., and Crummer, K.G. 2011. Holocene carbon stocks and carbon accumulation rates altered in soils undergoing permafrost thaw. Ecosystems, 15: 162-173. doi: 10.1007/s10021-011-9500-4.

Hicks Pries, C.E., Schuur, E.A.G., Vogel, J.G., and Natali, S.M. 2013. Moisture drives surface decomposition in thawing tundra. J. Geophys. Res.: Biogeosci. 118: 1133-1143. doi: 10.1002/jgrg.20089.

Hudson, J.M.G., and Henry, G.H.R. 2010. High Arctic plant community resists 15 years of experimental warming. J. Ecol. 98: 1035-1041. doi: 10.1111/j.1365-2745.2010.01690.x.

Icelandic Meteorological Office. 2018. Available from https://en.vedur.is/ [accessed 8 March 2018].

Jeanbille, M., Clemmensen, K., Juhanson, J., Michelsen, A., Cooper, E.J., Henry, G.H.R., et al. 2021. Site-specific responses of fungal and bacterial abundances to experimental warming in litter and soil across Arctic and alpine tundra. Arct. Sci. Available e-First. doi: 10.1139/as-2020-0053.

Jones, A., Stolbovoy, V., Tarnocai, C., Broll, G., Spaargaren, O., and Montanarella, L. 2010. Soil atlas of the northern circumpolar region. Institute for Environment and Sustainability, Ispra, Italy. doi: 10.2788/95795.

Jónsdóttir, I.S., Magnússon, B., Gudmundsson, J., Elmarsdóttir, Á., and Hjartarson, H. 2005. Variable sensitivity of plant communities in Iceland to experimental warming. Global Change Biol. 11: 553-563. doi: 10.1111/j.13652486.2005.00928.x.

Kemppinen, J., Niittynen, P., Virkkala, A.-M., Happonen, K., Riihimäki, H., Aalto, J., and Luoto, M. 2019. Woody plants constructing tundra soils. bioRxiv. doi: 10.1101/789743.

Keuskamp, J.A., Dingemans, B.J.J., Lehtinen, T., Sarneel, J.M., and Hefting, M.M. 2013. Tea Bag Index: a novel approach to collect uniform decomposition data across ecosystems. Methods Ecol. Evol. 4: 1070-1075. doi: 10.1111/2041-210X.12097.

Kuznetsova, A., Brockhoff, P.B., and Christensen, R.H.B. 2017. lmerTest Package: tests in linear mixed effects models. J. Stat. Softw. 82: 1-26. doi: 10.18637/jss.v082.i13.

McLaren, J.R., Buckeridge, K.M., van de Weg, M.J., Shaver, G.R., Schimel, J.P., and Gough, L. 2017. Shrub encroachment in Arctic tundra: Betula nana effects on above- and belowground litter decomposition. Ecology, 98: 1361-1376. doi: 10.1002/ecy.1790. PMID: 28263375.

Molau, U., and Mølgaard, P. 1996. International tundra experiment (ITEX) manual. Danish Polar Center, Copenhagen, Denmark.

Myers-Smith, I.H., and Hik, D.S. 2013. Shrub canopies influence soil temperatures but not nutrient dynamics: an experimental test of tundra snow-shrub interactions. Ecol. Evol. 3: 3683-3700. doi: 10.1002/ece3.710. PMID: 24198933.

Myers-Smith, I.H., Forbes, B.C., Wilmking, M., Hallinger, M., Lantz, T., Blok, D., et al. 2011. Shrub expansion in tundra ecosystems: dynamics, impacts and research priorities. Environ. Res. Lett. 6: 45509. doi: 10.1088/1748-9326/6/4/ 045509.

Parker, T.C., Subke, J.-A., and Wookey, P.A. 2015. Rapid carbon turnover beneath shrub and tree vegetation is associated with low soil carbon stocks at a subarctic treeline. Global Change Biol. 21: 2070-2081. doi: 10.1111/gcb.12793. PMID: 25367088.

Post, E., Alley, R., Christensen, T.R., Macias-Fauria, M., Forbes, B., Gooseff, M., et al. 2019. The polar regions in a $2^{\circ} \mathrm{C}$ warmer world. Sci. Adv. 5: eaaw9883. doi: 10.1126/sciadv.aaw9883. PMID: 31840060.

R Core Team. 2019. R: a language and environment for statistical computing. R Foundation for Statistical Computing, Vienna, Austria. Available from https://www.R-project.org.

Ripley, B., Venables, B., Bates, D.M., Hornik, K., Gebhardt, A., and Firth, D. 2020. Support functions and datasets for Venables and Ripley's MASS. Version 7.3-53.

Sarneel, J., Sundqvist, M., Molau, U., Björkman, M., and Alatalo, J. 2020. Decomposition rate and stabilization across six tundra vegetation types exposed to $>20$ years of warming. Sci. Total Environ. 724: 138304. doi: 10.1016/ j.scitotenv.2020.138304. PMID: 32408462.

Schuur, E.A.G., Vogel, J.G., Crummer, K.G., Lee, H., Sickman, J.O., and Osterkamp, T.E. 2009. The effect of permafrost thaw on old carbon release and net carbon exchange from tundra. Nature, 459: 556-559. doi: 10.1038/ nature08031. PMID: 19478781.

Sierra, C.A., Trumbore, S.E., Davidson, E.A., Vicca, S., and Janssens, I. 2015. Sensitivity of decomposition rates of soil organic matter with respect to simultaneous changes in temperature and moisture. J. Adv. Model. Earth Syst. 16: 335-356. doi: 10.1002/2014MS000358.

South, A. 2016. rworldmap: mapping global data.

Street, L.E., Garnett, M.H., Subke, J.-A., Baxter, R., Dean, J.F., and Wookey, P.A. 2020. Plant carbon allocation drives turnover of old soil organic matter in permafrost tundra soils. Global Change Biol. 26: 4559-4571. doi: 10.1111/ gcb.15134.

Tarnocai, C., Canadell, J.G., Schuur, E.A.G., Kuhry, P., Mazhitova, G., and Zimov, S. 2009. Soil organic carbon pools in the northern circumpolar permafrost region. Global Biogeochem. Cycles, 23: 1-11. doi: 10.1029/2008GB003327.

Thomas, H.J.D. 2018. Plant traits as predictors of ecosystem change and function in a warming tundra biome. PhD thesis, The University of Edinburgh, Edinburgh, UK.

Wickham, H. 2009. ggplot2: elegant graphics for data analysis. Springer-Verlag, New York, N.Y., USA.

Wickham, H., Averick, M., Bryan, J., Chang, W., McGowan, L.D.A., François, R., et al. 2019. Welcome to the Tidyverse. J. Open Source Softw. 4: 1686. doi: 10.21105/joss.01686. 